\title{
Prague and Beyond
}




\section{JEWISH CULTURE AND CONTEXTS}

Published in association with the Herbert D. Katz Center for Advanced Judaic Studies of the University of Pennsylvania

Series Editors: Shaul Magid, Francesca Trivellato, Steven Weitzman

A complete list of books in the series is available from the publisher. 


\section{PRAGUE AND BEYOND}

Jews in the Bohemian Lands

\section{Edited by \\ Kateřina Čapková and Hillel J. Kieval}

\section{$\overline{\text { PENN }}$}

UNIVERSITY OF PENNSYLVANIA PRESS

PHIL A DEL PHIA 
Copyright (c 2021 University of Pennsylvania Press

All rights reserved. Except for brief quotations used for purposes of review or scholarly citation, none of this book may be reproduced in any form by any means without written permission from the publisher.

Published by University of Pennsylvania Press Philadelphia, Pennsylvania 19104-4112 www.upenn.edu/pennpress

Printed in the United States of America on acid-free paper $\begin{array}{llllllllll}10 & 9 & 8 & 7 & 6 & 5 & 4 & 3 & 2 & 1\end{array}$

A catalogue record for this book is available from the Library of Congress.

ISBN 978-0-8122-5311-5 